\title{
Performance Characteristics of Enhanced Soil Blocks: A Quantitative Review
}

\author{
Humphrey Danso, Brett Martinson, Muhammad Ali and Catherine Mant \\ School of Civil Engineering and Surveying, University of Portsmouth, Portland Building, \\ Portland Street, Portsmouth PO13AH, UK \\ E-mails: humphrey.danso@port.ac.uk,brett.martinson@port.ac.uk,muhammad.ali@port.ac.uk \\ and catherine.mant@port.ac.uk
}

\begin{abstract}
Several studies have focused on improving the properties of soil blocks/bricks due to perceived and real strength and durability limitations. A review of 56 published studies is presented on the effect of stabilization on the performance characteristics of soil blocks. The review found that few studies have been conducted on durability properties of enhanced soil blocks as compared with physico-mechanical properties. Fibre-enhanced soil blocks tended to have peak performance with an optimal content that achieved maximum performance. The maximum performance improvement was generally less than a doubling of the strength of the soil without the fibres. Binders showed a continual improvement with greater concentrations, so much greater improvements can be obtained if the economic and social costs can be justified. Both fibres and binders have variable performance on water absorption with both reductions and increases possible. Generally, both fibre and binder inclusion in soil blocks enhance the performance characteristics of the blocks. Binders are typically more effective on a mass-fraction basis. However the supply of fibres is usually at a lower cost and a reduced environmental impact, and therefore may have a better performance on a per-cost or per-impact basis.
\end{abstract}

Keywords: bricks, building materials, earth construction, enhanced soil blocks, performance

\section{Introduction}

Soil block construction involves compressing a damp mixture of unprocessed earth that has suitable proportions of gravel, sand, silt and clay (sometimes with an added stabiliser) into a mould, creating individual blocks for construction of structures. Earth is one of the oldest building materials and has been used in the construction of shelters for thousands of years, and 
presently about one-third of the world's population continue to live in earthen buildings (UN Habitat, 2008). Earth is a cheap, environmentally friendly, socially accepted, easy to work with and abundantly available building material (Binici, Aksogan, \& Shah, 2005; Quagliarini \& Lenci, 2010), and this has called for a renewed interest over the past few years. It has largely been used for wall construction in buildings globally, predominantly in less developed countries (Ren \& Kagi, 1995), due to its social and economic benefits (Arumala \& Gondal, 2007). Environmental benefits of earthen structures include reduced pollution, embodied energy, carbon dioxide emissions, regulation of humidity and possible re-use of the earthen material (Lawrence, Heath \& Walker, 2008).

In addition, earth provides a cool room temperature due to its thermal insulation properties (Arumala \& Gondal, 2007). However, earth construction suffers from shrinkage, cracking, low strength, lack of durability and dimensional stability for building construction, so improvement of these properties would be beneficial to its users (Walker, 1995; Bahar, Benazzoug, \& Kenai, 2004; Danso, 2013; Harper, 2011; Riza, Rahman, \& Zaidi, 2011). In view of the above, several studies have focused on improving, stabilising, reinforcing or enhancing the properties of soil blocks or bricks in terms of strength, shrinkage, thermal conductivity, and durability in order to improve the material and make it socially acceptable.

A number of studies (Delgado \& Guerrero, 2006, 2007; Hejazi, Sheikhzadeh, Abtahi, \& Zadhoush, 2012; Pacheco-Torgal \& Jalali, 2012) have reviewed the volume of literature in the enhancement, stabilisation or reinforcement of soil blocks or bricks for construction purposes. One study (Hejazi et al., 2012) reviewed the history, benefits, application; and possible executive problems of using different types of natural and/or synthetic fibres in soil reinforcement. Another study (Pacheco-Torgal \& Jalali, 2012) reviewed some of the environmental benefits associated with earth construction including an overview about its past and present. It also included a review of economic issues, non-renewable resource consumption, waste generation, energy consumption, carbon dioxide emissions and indoor air quality. In addition (Delgado \& Guerrero, 2007) offered a useful global view of the different approaches, contributing to the production of a new standard, which was the main purpose of their review. The study (Delgado \& Guerrero, 2006) also reviewed the state of use of the earth building in Spain. It presented researching organisations, modern projects carried out and the existing manufacturers for compressed earth 
blocks, and also examine a pair of non-regulatory guides that could act as national reference documents.

There is a significant quantity of literature on the performance of enhanced soil blocks, but at present there is no overview of the data from these studies. There remains a need to quantitatively analyse the data in these published works in order to reveal the scale and trend of their results. It should serve as a useful first-stop for those unfamiliar with the wide literature in the field and as a useful synthesis of results for researchers needing performance data for determining economic viability, environmental impact or technical feasibility of enhanced earth block construction in-general before proceeding to more detailed experimentation and analysis of their particular soil. The range of data can also serve as an indication of expected performance ranges for experimenters to compare with their own results. This paper, therefore, reviews the existing published works on the effect of stabilisers (fibres and binders) on the technical performance of soil blocks or bricks using the performance measures of compressive strength, flexural and tensile strength and water absorption.

\section{Methodology}

The review adopted a quantitative approach. Numerical data from a number of previous studies' results were extracted and analysed to ascertain the effectiveness of stabilisation methods used. Fifty-six studies in all were consulted and useful data were found in twenty-five studies. Two broad categories of enhancement were analysed, fibres and binders. The fibres studied in the literature cover a broad range of natural and artificial fibres and were primarily obtained from agricultural and industrial residues. The binders include cement, lime, various polymers and other materials that either react with the soil or set into a crystal lattice after contact with water.

A wide range of tests exist for determining the technical performance of soil blocks. Authors decide on the types of test to conduct based on the focus of their study and sometimes the availability of test equipment. To compare data from the studies, their results were charted using a common format as a series of scatter diagrams as shown in Figure 1. The abscissa of the chart is the concentration of stabilisation used, consistently expressed as a mass fraction. In cases where authors expressed concentration in other units, such as volume fraction or as a part of a wider mix description, this was converted. The ordinate is the performance measure of interest expressed in constant units which depended on the performance measure. For each chart a 
regression line was drawn which could be one of two types. In cases where a clear maxima is indicated, a second order polynomial curve was fitted the data and the value corresponding to the maximum point on the curve was obtained. In cases where there was a simple trend upwards or downwards a simple linear fit was performed. The effectiveness of the stabilisation method in the region measured can be expressed in terms of the performance measure per mass of stabilisation added (e.g. MPa per \% added). It should be noted that it is very likely that that many stabilisation techniques will have a maximum performance at some concentration, so the effectiveness found can only be considered valid in the region studied.

Soil is a very non-homogenous material and therefore stabilisation is not the only factor that affects block performance. Compaction energy, soil characteristics such as particle size distribution and Atterberg limits, moisture content, drying regimen and other factors also have a large impact. As a result of this, a wide variation in unstabilised performance is expected and a subsequent range in stabilised performance. This review attempts to reduce this effect by reporting results in terms of additional performance achieved by the stabiliser rather than fractional improvement.

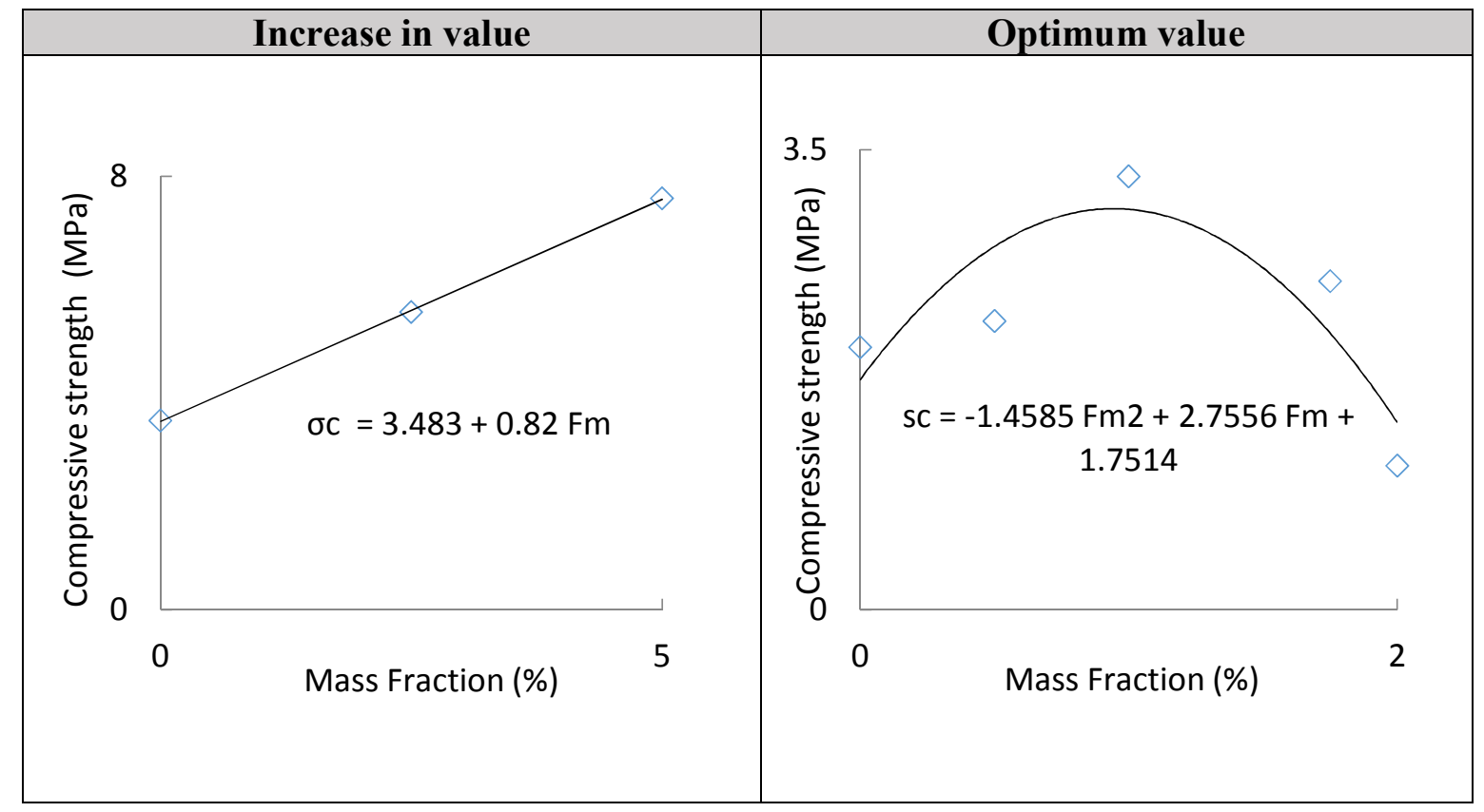

Figure 1: Scatter plot charts showing the trend values of the data 


\section{Stabilisation Methods}

The literature review found fifty-six studies which have investigated the use of stabilisation techniques and their effects. Table 1 outlines these stabilisation methods. Stabilisation of soil is the method of adding additional materials to the natural soil/earth in order to enhance its strength and/or other properties for the purpose of construction. According to Houben \& Guillaud (1994), stabilising soil "implies the modification of the properties of the soil-water-air system in order to obtain lasting properties which are compatible with a particular application...”. Minke (2009) extends this, stating that the aim of stabilisation is to increase the strength and durability properties of soil blocks for better resistance to applied load and weather. These improvements are made possible by incorporating into the soil other materials such as fibres and binders that will address some of the weaknesses (Ngowi, 1997). There are several ways of stabilising earth, which can be grouped by reinforcement (fibres and other waste), binders (cement, lime and other additives) and combination of the methods.

Table 1: Soil block/brick stabilisation methods

\begin{tabular}{|c|c|c|}
\hline Reference & Fibres & Binders \\
\hline Quagliarini \& Lenci (2010) & Straw & \\
\hline $\begin{array}{l}\text { Yetgin, Cavdar, \& Cavdar } \\
\text { (2008) }\end{array}$ & Straw & \\
\hline $\begin{array}{l}\text { Piattoni et, Quagliarini, \& } \\
\text { Lenci (2011) }\end{array}$ & Straw & \\
\hline $\begin{array}{l}\text { Bouhicha, Aouissi, \& Kenai } \\
(2005)\end{array}$ & Chopped barley straw & \\
\hline Maher \& Ho (1994) & $\begin{array}{l}\text { Polystyrene fibre, glass and softwood } \\
\text { pulp }\end{array}$ & \\
\hline $\begin{array}{l}\text { Elenga, Mabiala, Ahouet, } \\
\text { Goma-Maniongui, \& Dirras } \\
\text { (2011) }\end{array}$ & Polyethylene waste nets & \\
\hline $\begin{array}{l}\text { Akbulut, Arasan, \& Kalkan } \\
\text { (2007) }\end{array}$ & $\begin{array}{l}\text { Scrap tire rubber fibre, polyethylene } \\
\text { fibre and Polypropylene fibre }\end{array}$ & \\
\hline Yalley \& Kwan (2008) & Plastic fibre and palm fibres & \\
\hline Turgut \& Yesilata (2008) & Crumb rubber & \\
\hline $\begin{array}{l}\text { Kumar, Walia, \& Mohar } \\
\text { (2006) }\end{array}$ & Polyester fibre & \\
\hline $\begin{array}{l}\text { Ghavami, Filho, \& Barbosac } \\
\text { (1999) }\end{array}$ & Sisal fibre and coconut fibre & \\
\hline Gaw \& Zamora (2011) & Coconut fibre and coir fibre & \\
\hline Demir (2006) & Processed waste tea residue & \\
\hline Kavas (2006) & Boron waste & \\
\hline $\begin{array}{l}\text { Aymerich, Fenu, \& Meloni } \\
\text { (2012) }\end{array}$ & Sheep wool fibre & \\
\hline Sen \& Reddy (2011) & Sisal, Coir, Jute and hemp & \\
\hline
\end{tabular}




\begin{tabular}{|c|c|c|}
\hline $\begin{array}{l}\text { Millogo, Morel, Aubert \& } \\
\text { Ghavami (2014) }\end{array}$ & Hibiscus cannabinus fibre & \\
\hline Harper (2011) & & $\begin{array}{l}\text { Ground granulated blast furnance slag } \\
\text { and pulverised fly ash }\end{array}$ \\
\hline Degirmenci (2008) & & $\begin{array}{l}\text { Waste phosphogypsum and natural } \\
\text { gypsum }\end{array}$ \\
\hline Kouakou \& Morel (2009) & & Argillaceous minerals \\
\hline $\begin{array}{l}\text { Guettala, Houari, } \\
\text { Mezghiche, \& Chebili } \\
\text { (2002) }\end{array}$ & & Lime \\
\hline $\begin{array}{l}\text { Millogo, Hajjaji, \& } \\
\text { Ouedraog (2008) }\end{array}$ & & Lime \\
\hline Muntohar (2011) & & Lime and rice husk ash \\
\hline Reddy \& Lokras (1998) & & Lime \\
\hline Reddy \& Hubli (2002) & & Lime and fly ash \\
\hline Heathcote (1995) & & Cement \\
\hline Heathcote (2002) & & Cement \\
\hline Montgomery (2002) & & Cement \\
\hline $\begin{array}{l}\text { Bahar, Benazzoug, \& S. } \\
\text { Kenai (2004) }\end{array}$ & & Cement \\
\hline Millogo \& Morel (2012) & & Cement \\
\hline Reddy, Lal \& Rao (2007) & & Cement \\
\hline Walker (1995) & & Cement \\
\hline Walker \& Stace (1997) & & Cement \\
\hline Walker (2004) & & Cement \\
\hline $\begin{array}{l}\text { Morel, Pkla \& Walker } \\
(2007)\end{array}$ & & Cement \\
\hline Gooding \& Thomas (1997) & & Cement \\
\hline $\begin{array}{l}\text { Alavez-Ramirez, Montes- } \\
\text { Garcia, Martinez-Reyes, } \\
\text { Altamirano-Juarez, \& } \\
\text { Gochi-Ponce (2012) }\end{array}$ & & $\begin{array}{l}\text { cement, lime and sugar cane bagasse } \\
\text { ash }\end{array}$ \\
\hline Hossain \& Mol (2011) & & Cement kiln dust and volcanic ash \\
\hline Ngowi (1997) & & Cement, lime, cow-dung and bitumen \\
\hline Oti, Kinuthia, \& Bai (2009) & & Cement and lime \\
\hline $\begin{array}{l}\text { Hossain, Lachemi, \& Easa } \\
(2007)\end{array}$ & & Cement, lime and volcanic ash \\
\hline $\begin{array}{l}\text { Atzeni, Pia, Sanna, \& Spanu } \\
(2008)\end{array}$ & & $\begin{array}{l}\text { Hydraulic cements, lime and organic } \\
\text { polymers }\end{array}$ \\
\hline Burroughs (2006) & & Cement, lime and asphalt \\
\hline Oti \& Kinuthia (2012) & & Cement and lime \\
\hline Binici et al. (2005) & $\begin{array}{l}\text { Straw, plastic fibres and polystyrene } \\
\text { fibre }\end{array}$ & Cement \\
\hline Arumala \& Gondal (2007) & Kenaf fibre & Cement \\
\hline $\begin{array}{l}\text { Juárez, Guevara, Valdez, \& } \\
\text { Durán-Herrera (2010) }\end{array}$ & Lechuguilla natural fibre & Cement \\
\hline Vilane (2010) & Sawdust & Cement, molasses and cow-dung \\
\hline Chan (2011) & $\begin{array}{l}\text { Pineapple leaves fibre and oil palm } \\
\text { fruit bunch fibre }\end{array}$ & Cement \\
\hline Ismail \& Yaacob (2011) & Oil palm empty fruit bunches fibre & Cement \\
\hline $\begin{array}{l}\text { Medjo Eko, Offa, Ngatcha, } \\
\& \text { Minsili (2012) }\end{array}$ & Salvaged steel fibres from used tyres & Cement \\
\hline $\begin{array}{l}\text { Obonyo, Exelbirt \& } \\
\text { Baskaran (2010) }\end{array}$ & Coconut fibre & Cement and lime \\
\hline
\end{tabular}




\begin{tabular}{|l|l|l|}
\hline Cai, Shi, Ng, \& Tang (2006) & Polypropylene & Lime \\
\hline $\begin{array}{l}\text { (Villamizar, Araque, Reyes, } \\
\text { \& Silva, 2012) }\end{array}$ & Cassava peels & Coal combustion waste \\
\hline $\begin{array}{l}\text { (Galán-Marín, Rivera- } \\
\text { Gómez, \& Petric, 2010) }\end{array}$ & Sheep wool fibre & Alginate \\
\hline (Achenza \& Fenu, 2006) & Seaweed fibres and & Natural polymers \\
\hline
\end{tabular}

Seventeen Studies stabilised soil blocks or bricks with fibres and other industrial and agricultural by-products. This method has being followed since ancient times, for instance, in ancient Egypt, straw and horsehair were added to mud bricks, while straw mats were used as reinforcement in early Chinese and Japanese housing construction (Li, 2002). The inclusion of soil blocks with waste fibres has structural (improvement of strength and durability properties), economic (lowcost) and environmental (reduction of carbon dioxide and pollution) benefits. Thus, instead of disposing of waste in manner that can pollute the air, it is used in blocks for the purpose of increasing the strength and durability properties of the blocks as well as making them affordable. In the view of Al-Sakkaf (2009), constructing buildings that are durable and low-cost is a need and essential particularly for those in low income bracket. This is important because low-cost housing is described as dwelling units whose total housing costs for either rented or purchased units are deemed affordable to those that have a median household income (Bhatta \& Basudeb, 2010), as well as those in the low income bracket.

Twenty-seven studies followed the method that stabilized soil blocks or bricks with only binders. This method is not known only in the stabilisation of soil blocks but also applicable in conventional building materials like concrete and mortar. Cement and lime have proved that they are effective binding agents, but their manufacturing process tend to have long term detrimental effect on the health of people and environment. They also require high energy consumption for production. The energy requirement to produce unstabilised adobe blocks is only $5 \mathrm{kWh} / \mathrm{m}^{3}$, it is about $1000 \mathrm{kWh} / \mathrm{m}^{3}$ for fired bricks and $400-500 \mathrm{kWh} / \mathrm{m}^{3}$ for concrete (Al-Sakkaf, 2009). The production of Portland cement (PC) contributes significantly to anthropogenic $\mathrm{CO} 2$ emissions in the atmosphere (Kinuthia \& Mofor, 2010). Therefore, the partial or total replacement of PC is critical to the achievement of sustainable development of infrastructure. As the construction industry is becoming increasingly focused on sustainability, there is the need for alternate building materials that are environmentally friendly and consume less energy (UN Habitat, 2011). 
For further enhancement, twelve studies combined fibres and binders. Though most of the studies succeed in demonstrating greater improvement, there are still concerns about the manufacturing process of the binder component which can reduce the environmental differential between unfired and fired blocks as well as increasing the cost of producing housing.

\section{Properties and test methods}

From Table 2, the focus of previous studies can be categorised in three ways which are physical properties, mechanical properties and durability properties. A fourth category which is also important is combinations of these properties. These categorisations were made based on the types of test conducted in the previous studies which are detailed in Table 2.

Physical properties are properties other than mechanical properties that depend on the physics of the material, including density, porosity, shrinkage, water absorption, moisture content and thermal expansion. None of the studies focused only on physical properties, though they were often combined with mechanical properties as a comparison. This is because; physical property tests are often simple to carry out in the field and may sometimes be used to imply mechanical properties without the need for more complex mechanical testing.

Mechanical properties are those material properties that measure a material's reaction to applied force, such as tensile strength, compressive strength, flexural strength, modulus of elasticity and efflorescence. Eleven studies focused only on mechanical properties. Mechanical properties have been widely studied because it is felt that the perceived limitations of soil blocks are due to problems in mechanical properties.

Durability properties are the properties of a material that resist weathering action, chemical attack, and abrasion. Durability tests attempt to measure the bond holding particles within the wall under the action of simulated erosive forces (Heathcote, 1995). Five studies focused only on durability and in all only eleven studies included duribilty testing in their work. Those studies also use a wide range of techniques and performance measures that make comparison difficult. This is an indication that durability has seen little research work; however, it is an important test, particularly for high rainfall areas where erosion, blown dust and wear of the soil particles could be critical. 
Table 2: Types of Test Conducted by Previous Studies

\begin{tabular}{|c|c|c|c|c|c|c|c|c|c|c|c|c|c|c|c|c|}
\hline \multirow[t]{2}{*}{ Reference } & \multicolumn{6}{|c|}{ Physical Properties } & \multicolumn{5}{|c|}{ Mechanical Properties } & \multicolumn{5}{|c|}{ Durability Properties } \\
\hline & 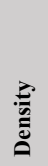 & $\begin{array}{l}\frac{2}{n} \\
\stackrel{0}{0} \\
\stackrel{0}{0}\end{array}$ & 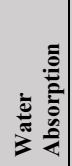 & 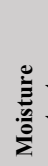 & 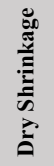 & 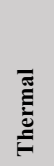 & 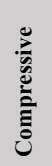 & 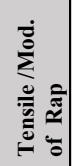 & 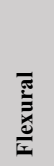 & $\begin{array}{l}\ddot{b} \\
\dot{a} \\
\bar{E} \\
\bar{\Xi} \\
\dot{z}\end{array}$ & 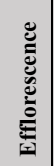 & 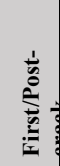 & 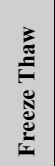 & 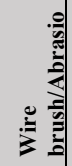 & 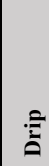 & क् \\
\hline Achenza \& Fenu (2006) & $\checkmark$ & $\checkmark$ & $\checkmark$ & & & & $\checkmark$ & & & & & & & & $\checkmark$ & \\
\hline Akbulut et al. (2007) & & & & & & & $\checkmark$ & & & & & & & & & \\
\hline Alavez-Ramirez et al. (2012) & & & & & & & $\checkmark$ & & $\checkmark$ & & & & & & & \\
\hline Arumala \& Gondal (2007) & $\checkmark$ & & $\checkmark$ & $\checkmark$ & & & $\checkmark$ & $\checkmark$ & & & & & & & & \\
\hline Atzeni et al. (2008) & & $\checkmark$ & & & $\checkmark$ & & $\checkmark$ & & & & & & & $\checkmark$ & & \\
\hline Aymerich et al. (2012) & & & & & & & & & & & & $\checkmark$ & & & & \\
\hline Bahar et al. (2004) & & & $\checkmark$ & & $\checkmark$ & & $\checkmark$ & $\checkmark$ & & & & & & & & \\
\hline Binici et al. (2005) & $\checkmark$ & & $\checkmark$ & & & & $\checkmark$ & & & & & & & & & \\
\hline Bouhicha et al. (2005) & & & & & $\checkmark$ & & $\checkmark$ & & $\checkmark$ & & & & & & & \\
\hline Burroughs (2006) & & & & & & & $\checkmark$ & & & & & & & & & \\
\hline Cai et al. (2006) & $\checkmark$ & & & $\checkmark$ & $\checkmark$ & & $\checkmark$ & & & & & & & & & \\
\hline Chan (2011) & $\checkmark$ & & $\checkmark$ & & & & $\checkmark$ & & & $\checkmark$ & $\checkmark$ & & & & & \\
\hline Degirmenci (2008) & & & & & $\checkmark$ & & $\checkmark$ & & $\checkmark$ & & & & & & & \\
\hline Demir (2006) & $\checkmark$ & $\checkmark$ & $\checkmark$ & & $\checkmark$ & & $\checkmark$ & & & & & & & & & \\
\hline Elenga et al. (2011) & $\checkmark$ & & & $\checkmark$ & $\checkmark$ & & $\checkmark$ & & $\checkmark$ & $\checkmark$ & & & & & & \\
\hline Galán-Marín et al. (2010) & $\checkmark$ & & & & & & $\checkmark$ & & & & & & & & & \\
\hline Ghavami et al (1999) & & & $\checkmark$ & & & & $\checkmark$ & $\checkmark$ & & & & & & & & \\
\hline Gaw \& Zamora (2011) & & & & & $\checkmark$ & & $\checkmark$ & & & & & & & & & \\
\hline Gooding \& Thomas (1997) & $\checkmark$ & & & & & & $\checkmark$ & & & & & & & & & \\
\hline Guettala et al. (2002) & & & & & & & & & & & & & $\checkmark$ & & & \\
\hline Harper (2011) & & & $\checkmark$ & & & & $\checkmark$ & & & & & & & & & \\
\hline Heathcote (1995) & & & & & & & & & & & & & & & $\checkmark \checkmark$ & $\checkmark$ \\
\hline Heathcote (2002) & & & & & & & & & & & & & & & & $\checkmark$ \\
\hline Hossain et al. (2007) & $\checkmark$ & & $\checkmark$ & $\checkmark$ & $\checkmark$ & & $\checkmark$ & $\checkmark$ & & $\checkmark$ & & & & & & \\
\hline Hossain \& Mol (2011) & $\checkmark$ & & $\checkmark$ & & $\checkmark$ & & $\checkmark$ & $\checkmark$ & & $\checkmark$ & & & & & & \\
\hline Ismail \& Yaacob (2011) & $\checkmark$ & & $\checkmark$ & & & & $\checkmark$ & & & & & & & & & \\
\hline Juárez et al. (2010) & $\checkmark$ & & & & $\checkmark$ & & $\checkmark$ & $\checkmark$ & & & & $\checkmark$ & & & & \\
\hline Kavas (2006) & & & $\checkmark$ & & $\checkmark$ & & $\checkmark$ & & & & & & & & & \\
\hline Kouakou \& Morel (2009) & & $\checkmark$ & & & $\checkmark$ & & $\checkmark$ & & & & & & & & & \\
\hline Kumar et al. (2006) & $\checkmark$ & & & & & & $\checkmark$ & & & & & & & & & \\
\hline Maher \& Ho (1994) & & & & & & & $\checkmark$ & $\checkmark$ & $\checkmark$ & & & & & & & \\
\hline Medjo Eko et al. (2012) & $\checkmark$ & & & & & & $\checkmark$ & $\checkmark$ & $\checkmark$ & & & & & & & \\
\hline Millogo et al. (2008) & & & $\checkmark$ & & & & $\checkmark$ & & $\checkmark$ & & & & & & & \\
\hline Millogo \& Morel (2012) & & & $\checkmark$ & & & & $\checkmark$ & & $\checkmark$ & & & & & & & \\
\hline Millogo et al. (2014) & & & & & & $\checkmark$ & $\checkmark$ & & $\checkmark$ & & & & & $\checkmark$ & & $\checkmark$ \\
\hline Montgomery (2002) & $\checkmark$ & & & & & & $\checkmark$ & & & & & & & & & \\
\hline Morel et al. (2007) & $\checkmark$ & & & & & & $\checkmark$ & & $\checkmark$ & & & & & & & \\
\hline Muntohar (2011) & & & $\checkmark$ & & & & $\checkmark$ & $\checkmark$ & $\checkmark$ & & & & & & & \\
\hline Ngowi (1997) & $\checkmark$ & & $\checkmark$ & & & & $\checkmark$ & & & & & & & $\checkmark$ & & \\
\hline Obonyo et al. (2010) & & & & & & & & & & & & & & & & $\checkmark$ \\
\hline Oti et al. (2009) & & & & & & & $\checkmark$ & & & & & & & & & \\
\hline Oti \& Kinuthia (2012) & & & & & & & $\checkmark$ & & & & & & & & & \\
\hline Piattoni et al. (2011) & & & & & & & $\checkmark$ & & & $\checkmark$ & & & & & & \\
\hline Quagliarini \& Lenci (2010) & & & & & & & $\checkmark$ & & & $\checkmark$ & & & & & & \\
\hline Reddy \& Lokras (1998) & & & & & & & $\checkmark$ & & & & & & & & & \\
\hline Reddy \& Hubli (2002) & & & & & & & $\checkmark$ & & & & & & & & & \\
\hline Reddy et al. (2007) & & & $\checkmark$ & & & & $\checkmark$ & & $\checkmark$ & & & & & & & \\
\hline Sen \& Reddy (2011) & $\checkmark$ & & $\checkmark$ & $\checkmark$ & & & $\checkmark$ & $\checkmark$ & & $\checkmark$ & & & & & & \\
\hline Vilane (2010) & & & & & & & $\checkmark$ & & & & & & & & & \\
\hline Villamizar et al. (2012) & & & $\checkmark$ & & & & $\checkmark$ & & $\checkmark$ & & & & & & & \\
\hline Walker (1995) & $\checkmark$ & & & & $\checkmark$ & & $\checkmark$ & $\checkmark$ & & & & & & & & \\
\hline Walker \& Stace (1997) & $\checkmark$ & & $\checkmark$ & & $\checkmark$ & & $\checkmark$ & & & & & & & & & \\
\hline Walker (2004) & & & & & & & $\checkmark$ & $\checkmark$ & & & & & & $\checkmark$ & & $\checkmark$ \\
\hline
\end{tabular}




\begin{tabular}{|c|c|c|c|c|c|c|c|c|c|c|c|c|c|c|c|c|}
\hline \multirow[t]{2}{*}{ Reference } & \multicolumn{6}{|c|}{ Physical Properties } & \multicolumn{5}{|c|}{ Mechanical Properties } & \multicolumn{5}{|c|}{ Durability Properties } \\
\hline & 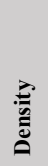 & 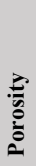 & 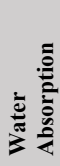 & 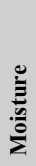 & 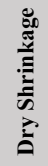 & 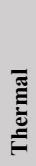 & 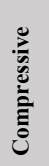 & 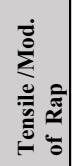 & 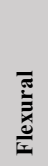 & 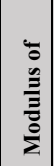 & 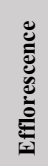 & 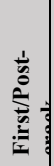 & 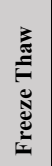 & 吾 & 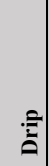 & $\vec{n}$ \\
\hline Yalley \& Kwan (2008) & & & & & & $\checkmark$ & $\checkmark$ & & & & & & & & & \\
\hline Yetgin et al. (2008) & $\checkmark$ & $\checkmark$ & $\checkmark$ & & & & $\checkmark$ & & & & & & & & & \\
\hline \multirow[t]{2}{*}{ Total } & 22 & 5 & 21 & 5 & 15 & 2 & 50 & 12 & 13 & \begin{tabular}{|l|}
7 \\
\end{tabular} & 1 & 2 & 1 & 4 & 2 & 5 \\
\hline & \multicolumn{6}{|c|}{70} & \multicolumn{5}{|c|}{83} & \multicolumn{5}{|c|}{14} \\
\hline
\end{tabular}

Thirty-four studies combined at least two properties while five studies combined physical, mechanical and durability. This is becoming popular because it offers researchers a variety of tests to investigate the broader properties of enhanced soil blocks.

\section{Results}

\section{Compressive Strength}

Twenty-three of the studies conducted compressive strength tests on stabilised soil blocks/bricks and their results are presented in Table 3 (with fibres) and Table 4 (with binders). The Turkish standard code for the compressive strength of unfired clay brick is $1 \mathrm{MPa}$ (Turkish Standard (TS 704), 1983, 1985), while Houben \& Guillaud (1994) recommended at least 2 MPa for cement stabilised blocks.

Table 3: Compressive Strength (with Fibre)

Abscissa is mass fraction (\%), ordinate is compressive strength (MPa)

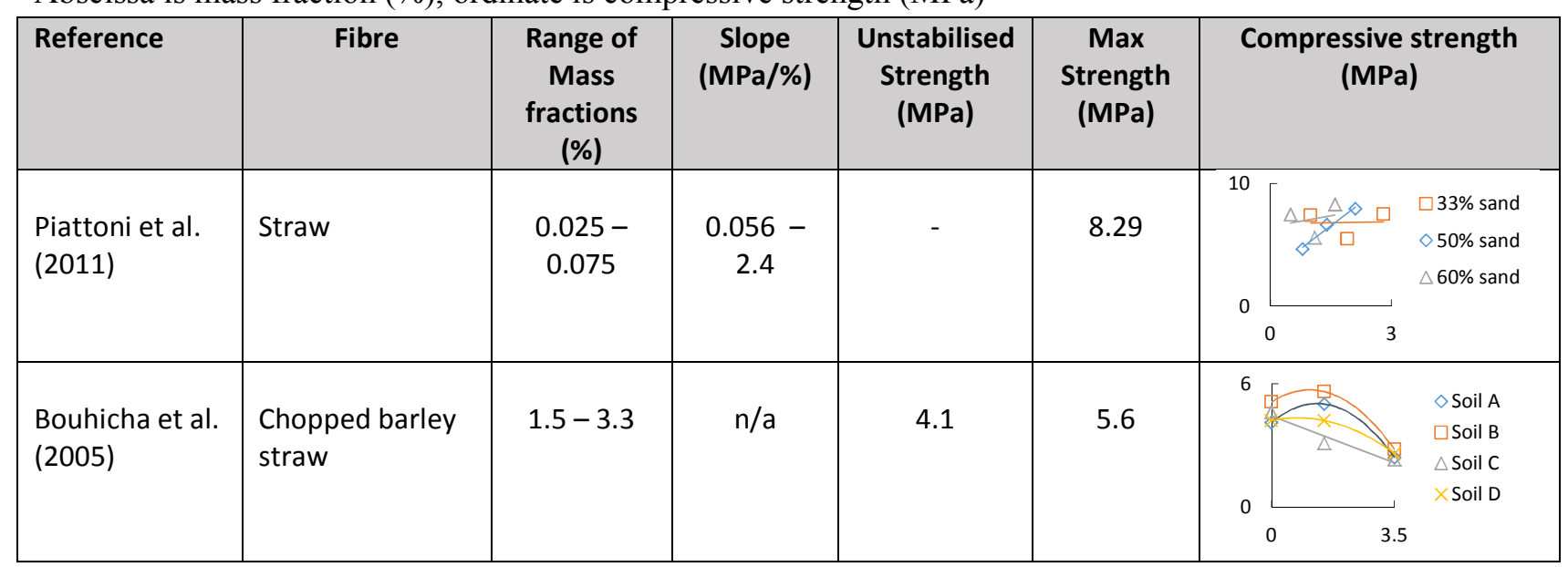




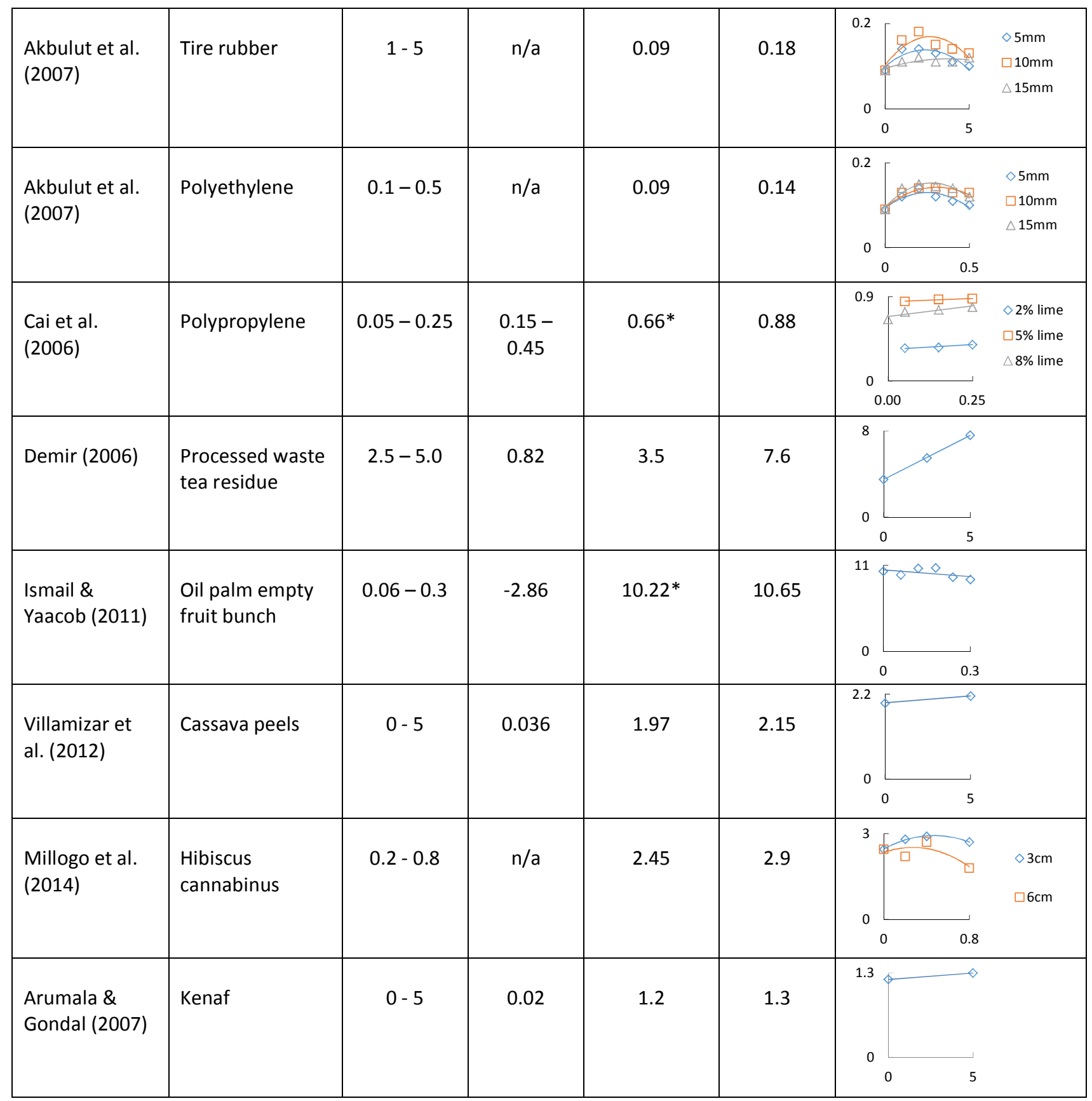

* "Unstabilised" strength is with a binder, but no fibre. Binder content is kept constant

Table 3 shows nine studies that conducted compressive strength tests with various fibres as the enhancement agent. The results show the three types of trend. 1, a slope with a positive gradient indicating an increase in compressive strength with additional fibres, 2, a slope with a negative gradient indicating a falling strength with additional fibres and 3, a rise to a maxima followed by a fall. The gradients, cover a wide range with a minimum of $-2.86 \mathrm{MPa}$ per $\%$ added, a maximum 
of $2.4 \mathrm{MPa}$ per $\%$ added and a median of $0.8 \mathrm{MPa}$ per \% added. Five of the studies (Arumala \& Gondal, 2007; Cai et al., 2006; Demir, 2006; Piattoni et al., 2011; Villamizar et al., 2012) obtained a positive gradient, while (Ismail \& Yaacob, 2011) obtained a negative trend. The balance of the papers (Akbulut et al., 2007; Bouhicha et al., 2005; Millogo et al., 2014) show a definite optimum fibre content. This content varies between $0.1 \%$ and $5 \%$ with a median of $1.0 \%$. Fibres initially work by increasing the bond between the particles both by friction on the fibre and by tying them together with loops. The fibres have a greater tensile strength than the surrounding soil matrix and therefore impart a greater cohesion and strength (Cai, et al, 2006; Millogo et al., 2014). The effect peaks at some concentration and then fibres begin to bunch together (Ismail \& Yaacob, 2011) and lose cohesion with the soil (Medjo Eko et al, 2012) and also break-up the soil matrix (Millogo et al., 2014) causing the soil-fibre composite to weaken. It is likely that those studies that found a consistently rising strength have yet to achieve the peak. Of the studies that did not include a binder as well as fibres, the lowest optimum found was 0.14 $\mathrm{MPa}$ which is well under the recommendations, and the highest from soil stabilised by only fibre was 8.29 MPa. Soils alone varied from 0.09 $\mathrm{MPa}$ to $5.15 \mathrm{MPa}$ and the improvement due to fibres alone ranged from $0.04 \mathrm{MPa}$ to $1.17 \mathrm{MPa}$ with a median of $0.43 \mathrm{MPa}$. Interestingly, the improvement followed the soil strength very well with the exception of Ismail \& Yaacob (2011). Pearson's coefficient is $r=0.8$ without Ismail \& Yaacob but only $r=0.09$ with it. This demonstrates the importance of the soil matrix for the effectiveness of fibre reinforcement. As the soil matrix is so important, the fractional improvement obtained with fibres was found to be in a quite narrow range ( $4 \%$ to $117 \%$ with a median of $26 \%)$.

Table 4 presents the result of compressive strength tests of soil blocks enhanced with different types of binder from seventeen published studies.

Table 4: Compressive Strength (with Binder)

Abscissa is mass fraction (\%), ordinate is compressive strength (MPa)

\begin{tabular}{|l|c|c|c|c|c|c|}
\hline Reference & Binder & $\begin{array}{c}\text { \% } \\
\text { Binder } \\
\text { (Range) }\end{array}$ & $\begin{array}{c}\text { Slope } \\
\text { (MPa/\%) }\end{array}$ & $\begin{array}{c}\text { Unstabilised } \\
\text { Strength } \\
\text { (MPa) }\end{array}$ & $\begin{array}{c}\text { Max } \\
\text { strength } \\
\text { (MPa) }\end{array}$ & $\begin{array}{c}\text { Compressive strength } \\
\text { (MPa) }\end{array}$ \\
\hline $\begin{array}{l}\text { Achenza \& } \\
\text { Fenu (2006) }\end{array}$ & natural polymer & $0-10$ & 0.19 & $2.5^{*}$ & 4.4 & \\
\hline
\end{tabular}




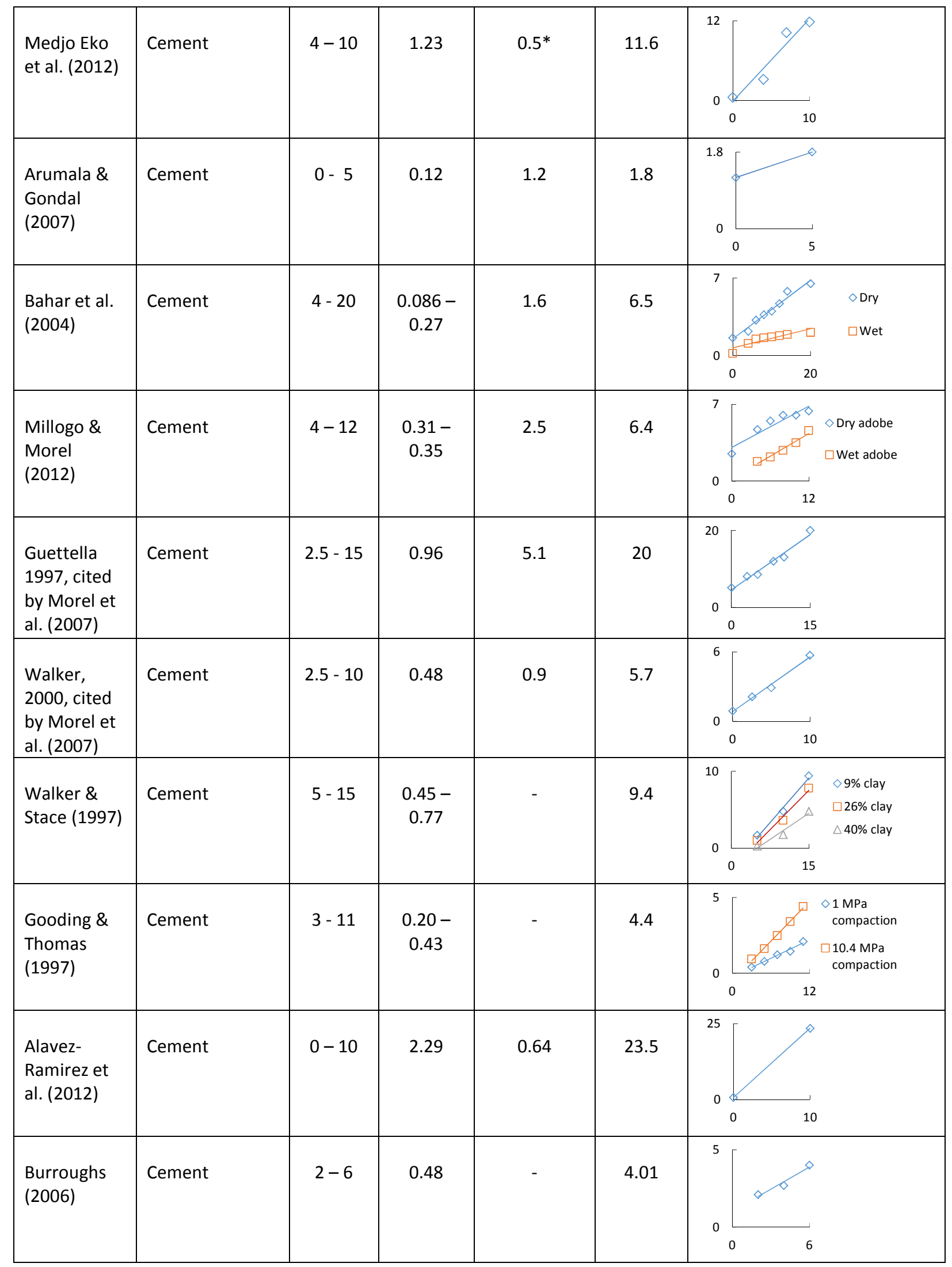




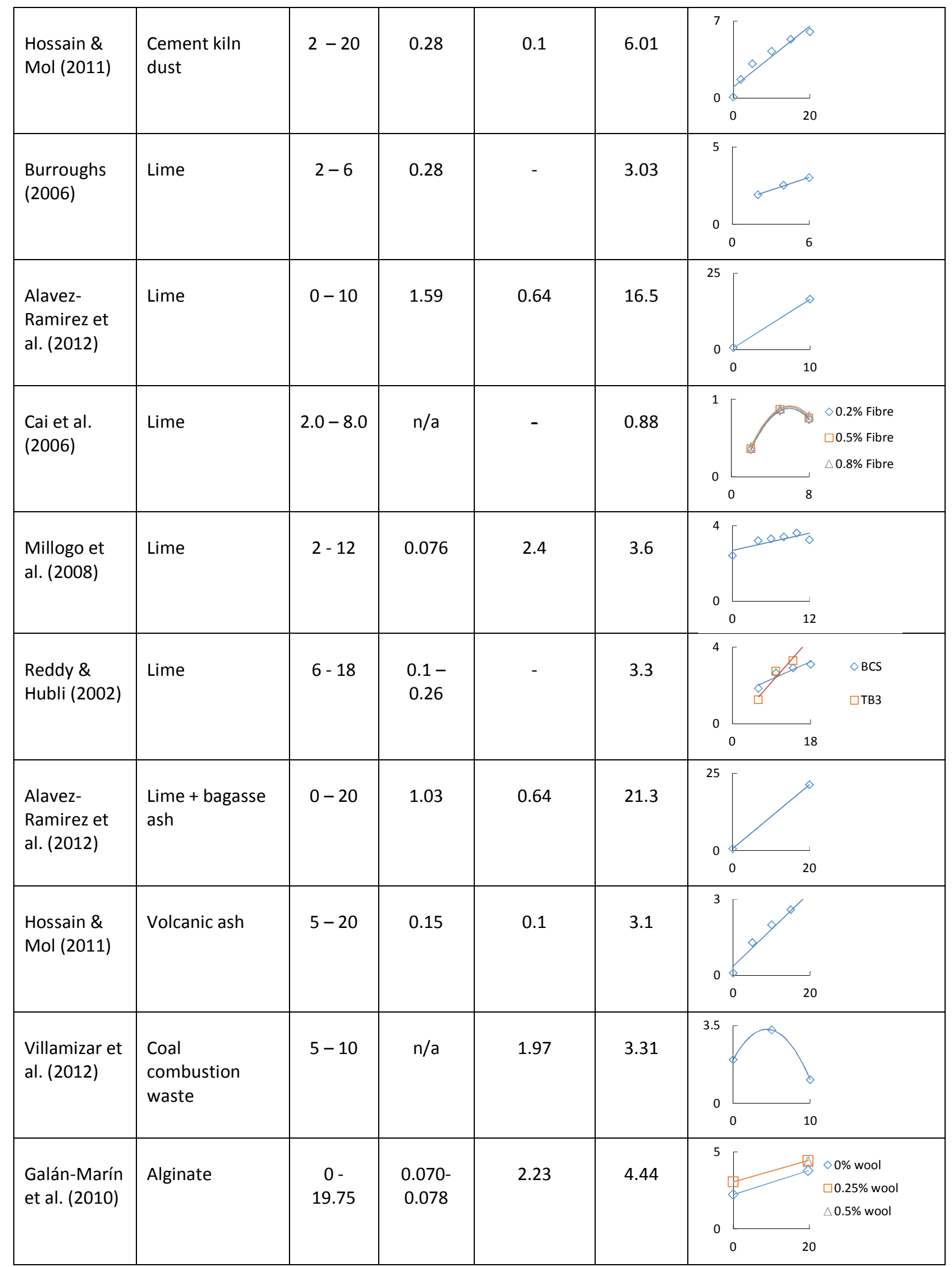




\begin{tabular}{|l|l|l|l|l|l|l|}
\hline $\begin{array}{l}\text { Degimenci } \\
\text { (2008) }\end{array}$ & Gypsum & $5-25$ & $\begin{array}{c}0.13- \\
0.16\end{array}$ & 1.0 & 4.6 & 5 \\
& & & & $\underbrace{25}_{0}$ \\
\hline
\end{tabular}

* "Unstabilised" strength is with fibres, but no binder. Fibre content is kept constant.

The results indicate that the vast majority of the studies had a positive gradient indicating that an increase in binder results in an increase in compressive strength. This increase ranged from 0.07 MPa per \% added to 2.29 MPa per \% added with a median of $0.28 \mathrm{MPa}$ per $\%$ added. In terms of compressive strength improvement, Portland cement is the most successful binder but also the most variable (range $=0.09-2.29 \mathrm{MPa} / \%$, median $=0.54 \mathrm{MPa} / \%$ ). Portland cement has the advantage of reacting with water forming various strong and rigid hydrates which fill spaces and bind particles together independent of reactions with the soil (Bahar et al., 2004; Millogo \& Morel, 2012). Though pozzolanic reactions with clays in the soil will occur, they play a small part in strength formation (Millogo \& Morel, 2012) and are smaller than the disadvantages associated with clay in the soil (Walker \& Stace, 1997). This is followed by materials relying on pozzolanic reactions such as volcanic ash $(0.15 \mathrm{MPa} / \%)$ and cement kiln dust $(0.28 \mathrm{MPa} / \%)$ and lime. Finally, materials that set around the particles rather than react with them such as gypsum $(0.16 \mathrm{MPa} / \%)$ and then polymers (Alginate $-0.08 \mathrm{MPa} / \%)$. As many binder reactions do not appear to level off in the regions studied, maximum strength is likely to be an economic or environmental rather than technical constraint, however as an indication of scale within the region of the studies analysed which range from $1 \%$ to $20 \%$, the maximum compressive strength recorded was $21 \mathrm{MPa}$ of which $20 \mathrm{MPa}$ was improvement from the cement binder at a $10 \%$ mass fraction. An exception to this trend was lime which relies on pozzolanic reactions with clays (Millogo et al, 2008). Once clays are all reacted, the lime simply forms a filler material which is porous and weak (Reddy \& Hubli, 2002; Muntohar, 2011). The optimum concentration of lime, therefore is dependent on the clay content of the soil but varies between $1.5 \%$ and $14 \%$ in the studies including lime as a binder. The performance of the binders was relatively insensitive to initial strength of the soil and the range of fractional improvement was from 50\% to 5900\%, though there is no reason to assume that this couldn't be improved upon if it were desirable to do so. As the use of binders enhances the strength of the soil matrix by increased cohesion between particles, their use also should also aid the pull-out performance of fibres and therefore the performance of fibre stabilised blocks. Four studies combined fibres and binders, however the 
results were, in fact quite similar to those for soil without binders. The median improvement for fibres in a binder-stabilised soil was $0.22 \mathrm{MPa}$, whereas the medium improvement for natural soils was $0.33 \mathrm{MPa}$. It is likely that other factors such as compression and clay content have contributed as much to fibre effectiveness as binder content.

\section{Water Absorption}

Ten studies conducted a water absorption test. Of these, eight were stabilised through a binder and two through fibres. The results of the studies are presented in Table 5.

Table 5: Water Absorption

Abscissa is mass fraction (\%), ordinate is Water absorption (\% by mass)

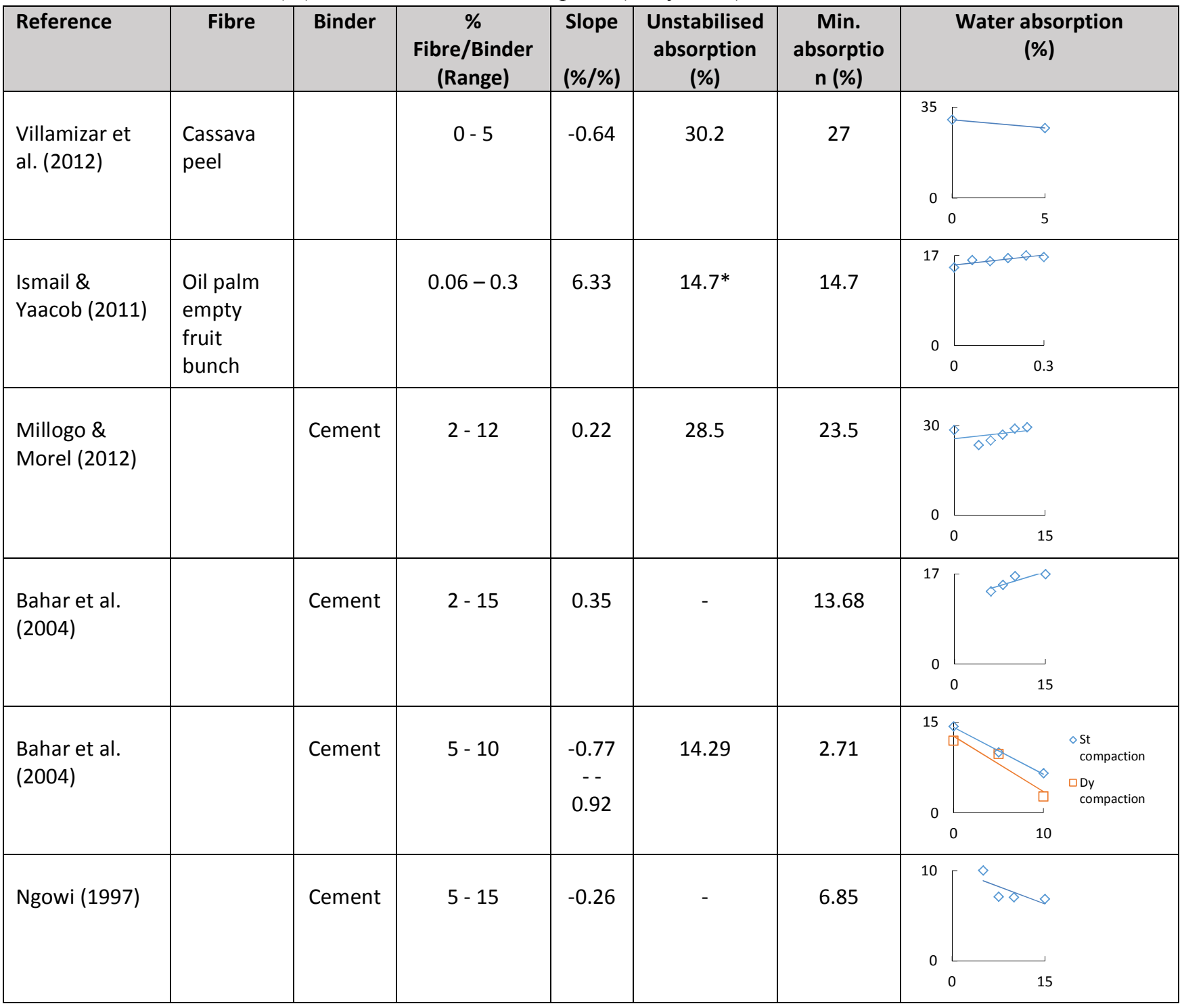




\begin{tabular}{|c|c|c|c|c|c|c|c|c|}
\hline $\begin{array}{l}\text { Reddy et al. } \\
(2007)\end{array}$ & Cement & $4-8$ & $\begin{array}{c}0.05- \\
0.18\end{array}$ & - & 14.66 & $\begin{array}{l}16 \\
0\end{array}$ & ${ }_{8}$ & $\begin{array}{l}\triangle 0 \% \text { sand } \\
\square 25 \% \text { sand } \\
\triangle 50 \% \text { sand } \\
\times 75 \% \text { sand }\end{array}$ \\
\hline $\begin{array}{l}\text { Walker \& } \\
\text { Stace (1997) }\end{array}$ & Cement & $5-10$ & $\begin{array}{c}0.08- \\
0.30\end{array}$ & - & 13.1 & $\begin{array}{l}30 \\
0\end{array}$ & $\underset{10}{\Delta \quad \Delta}$ & $\begin{array}{l}\diamond 9 \% \text { clay } \\
\square 26 \% \text { clay } \\
\triangle 40 \% \text { clay }\end{array}$ \\
\hline $\begin{array}{l}\text { Hossain \& Mol } \\
\text { (2011) }\end{array}$ & $\begin{array}{l}\text { Cement } \\
\text { kiln } \\
\text { dust }\end{array}$ & $2-20$ & -0.53 & 20.7 & 7.5 & 0 & $\tau_{20}$ & \\
\hline Ngowi (1997) & Lime & $5-15$ & 0.04 & - & 8.52 & $\begin{array}{l}10 \\
0\end{array}$ & $\diamond \diamond$ & \\
\hline $\begin{array}{l}\text { Millogo et al. } \\
\text { (2008) }\end{array}$ & Lime & $2-12$ & -0.89 & 29 & 19 & 0 & 12 & \\
\hline $\begin{array}{l}\text { Villamizar et } \\
\text { al. (2012) }\end{array}$ & $\begin{array}{c}\text { Coal } \\
\text { combus } \\
\text { tion } \\
\text { waste }\end{array}$ & $5-10$ & 0.045 & 30.2 & 28.7 & $\begin{array}{l}35 \\
0\end{array}$ & 10 & \\
\hline $\begin{array}{l}\text { Hossain \& Mol } \\
\text { (2011) }\end{array}$ & $\begin{array}{l}\text { Volcanic } \\
\text { ash }\end{array}$ & $5-20$ & -0.58 & 20.7 & 8.5 & 0 & 20 & \\
\hline
\end{tabular}

* "Unstabilised" contains none of the stabilisation of interest, but contains other stabilisers which are kept constant throughout.

The results for binders indicate variable and fairly neutral water absorption with additional binders. The range recorded was $-0.89 \%$ additional absorption for each $\%$ of increase in binder (\%/\%) to $0.35 \% / \%$ with a median of $0.02 \% / \%$ with half the papers reporting an increase and half a decrease. Explanations about the decrease in absorption are that the binder fills the void between particles reducing porosity, but no explanations about increased absorption were offered in the literature. There were few studies of fibres that included water absorption. A number of wider studies attempted to soak a block without binders in water and, predictably, found that it 
quickly disintegrated, so the available studies were restricted to blocks with a combination of binders and fibres. One study (Villamizar et al., 2012) recorded a slight reduction in water absorption with fibres $(-0.64 \% / \%)$ and the other (Ismail \& Yaacob, 2011) a significant increase $(6.33 \% / \%)$. It is likely that in-general, fibres will increase water absorption as the absorbent nature of fibres creates pathway through soil blocks, thereby allowing more water absorption (Ghavami et al, 1999)

\section{Flexural and Tensile Strength}

Ten studies conducted flexural strength test of enhanced soil blocks. The results are presented in Table 6.

Table 6: Flexural and Tensile Strength Abscissa is mass fraction (\%), ordinate is Flexural or tensile strength (MPa)

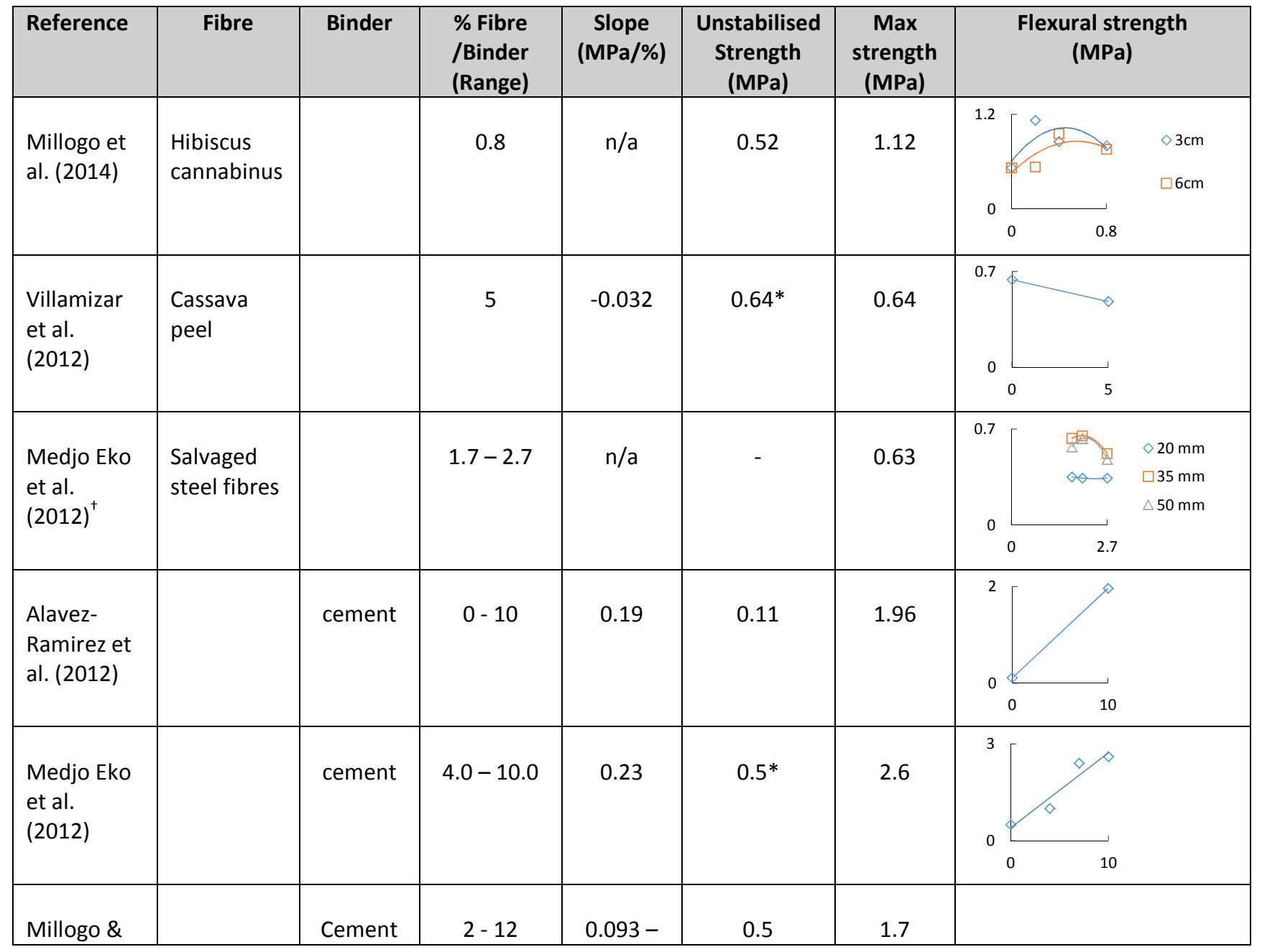




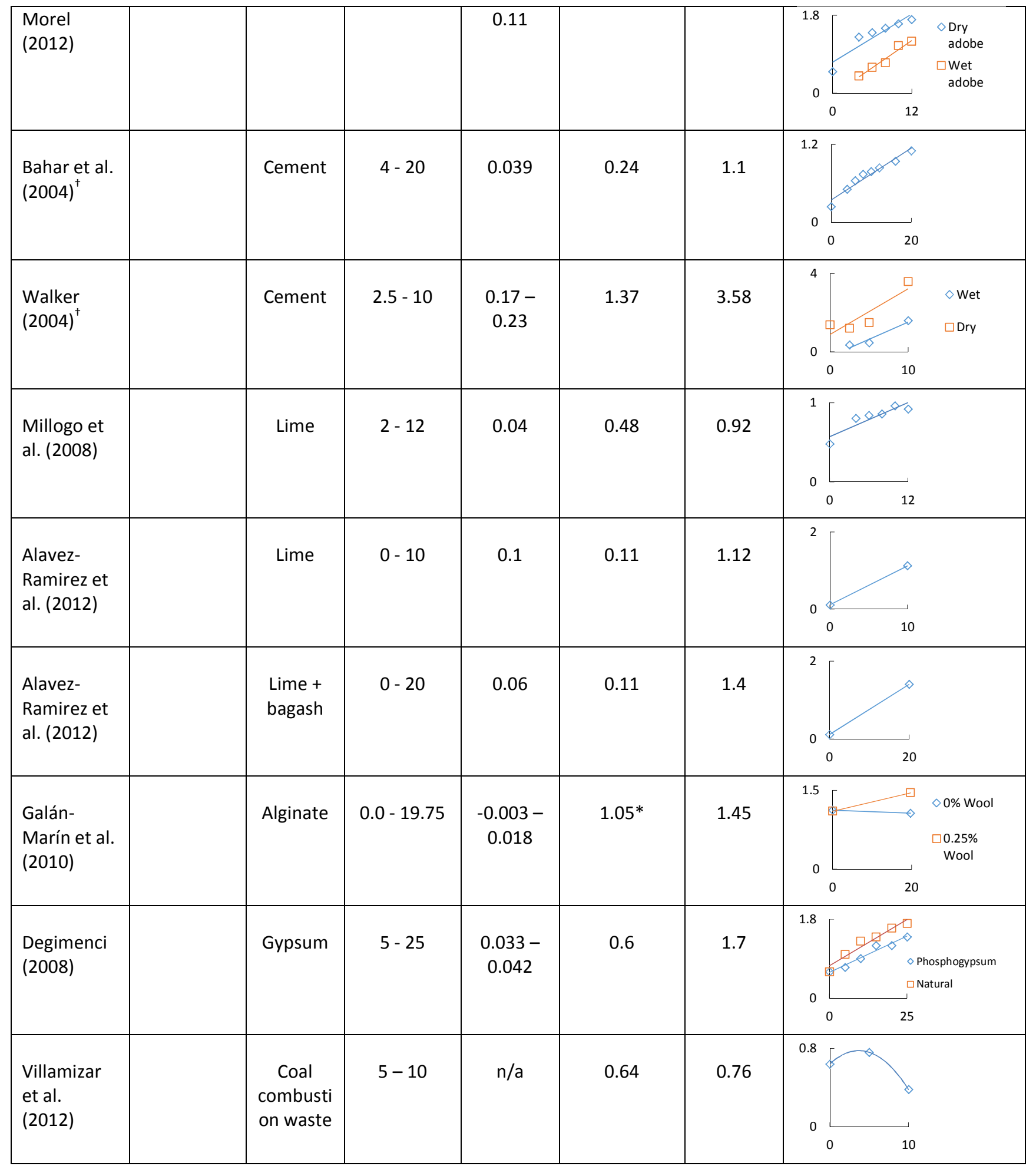

* "Unstabilised" contains none of the stabilisation of interest, but contains other stabilisers which are kept constant throughout.

${ }^{+}$Tensile strength 
The result show a very similar trend of results to compressive strength, with binders showing a generally rising flexural strength with increased concentration and fibres showing a maximum value. There were very few studies with fibres and so the maxima recorded must be considered as tentative. Millogo et al. (2014) report a maximum of $1.12 \mathrm{MPa}$, an improvement of $0.6 \mathrm{MPa}$ which compares to an improvement of $0.45 \mathrm{MPa}$ for compressive strength from the same study, so the ratio of flexutal to compressive strength improvement $\left(\sigma_{\mathrm{f}, \max } / \sigma_{\mathrm{c}, \max }\right)$ is $133 \%$.

Conversely, Villamizar et al., (2012) reported a reduction in flexural strength, however these results are based on only two points, one with fibers and one without and so is unlikely to represent an optimum fibre content. The median overall strength achieved was $0.6 \mathrm{MPa}, 22 \%$ of the median compressive strength achieved with fibres. A notable feature of fibres in both tension and compression is that the failure is more gradual, acting more like a ductile than a brittle material (Cai et al. 2006). This is ascribed to the fibres changing large cracks to many microcracks which hold the soil particles together (Medjo Eko et al., 2012) and form a bridge after the soil has cracked (Aymerich et al., 2012). It has also been proposed that fibres act to reduce the propagation of cracks in the soil matrix (Millogo et al., 2014).

More studies were available involving a range of binders. The maximum recorded flexural strength improvement was $2.2 \mathrm{MPa} 11 \%$ of the maximum compressive strength improvement, however as with compressive strength, this is likely to be a socioeconomic choice. More relevant for a binder is the rate of improvement. The maximum change is $0.24 \mathrm{MPa} / \%$ which is $10 \%$ of the maximum rate of improvement for compressive strength. The median change of strength imparted by a binder is $0.1 \mathrm{MPa} / \%$ and the median ratio of flexural to compressive strength change was $25 \%$. The hierarchy of binders was also similar to that found for compressive strength with cement displaying the highest and most variable improvement (range $=0.003-$ $0.24 \mathrm{MPa} / \%$, median $=0.10 \mathrm{MPa} / \%$ ). Next, Pozzolanic additives and lime (range $=0.04-0.1$ $\mathrm{MPa} / \%$, median $=0.06 \mathrm{MPa} / \%)$ and then other non-reactive materials such as Gypsum $(0.042$ $\mathrm{MPa} / \%)$ and Alginate $(0.018 \mathrm{MPa} / \%)$. One study of a pozzolanic material (Villamizar et al., 2012) showed a clear optimal concentration and another with lime (Millogo \& Morel, 2012) showed a weak optimum.

\section{Conclusions}


Based on the review of the performance characteristics of enhanced soil blocks or bricks, the following concluding remarks can be made:

1. Few studies focused on improving the durability property of enhanced soil blocks which is one of the major problems with earthen construction, while the majority of the previous studies were found testing for physical and mechanical properties.

2. Studies that enhanced the soil blocks or bricks with fibres mostly recorded an increase in compressive strength until an optimum was reached at a median strength of $0.43 \mathrm{MPa}$ above the unstabilised soil strength, and then further fibres reduced the strength of the block. This optimum varied, but was in the very low percentages with a median value of $1 \%$. The effectiveness of fibres was also very dependent on the soil matrix and can be considered to be capable of improving the strength of a block by up to $117 \%$, but more likely to be in the region of $20-50 \%$. The addition of binders generally continually increased the strength of the block with a median improvement of $0.28 \mathrm{MPa}$ per $\%$ added with the exception of lime which relies on reactions with clay and therefore has an optimal concentration which depends on the clay content. It is likely that other materials relying on pozzelanic reactions would have a similar peak, however this was not shown in the studies found.

3. Flexural strength displays very similar behaviour to compressive strength, but based on only a couple of studies, fibres appear to have a proportionally better performance. Fibres also make the blocks fail more gradually which may be important for earthquake prone areas. As with compressive strength, the addition of binders generally improves flexural strength, however materials which rely on pozzolanic reactions don't display as pronounced a defined maxima as with compressive strength.

4. The inclusion of stabilisers has a very variable effect on water absorption with as many studies reporting an increased absorption as a decreased absorption. This is contrary to received wisdom which states that binders should reduce water ingress and fibres should increase it.

The review concludes that, in general, fibre and binder inclusion in soil blocks enhances the performance characteristics of the blocks. This paper reviewed the existing published works on the effect of stabilisation on the performance characteristics of soil blocks. Binders are, in 
general more effective on a mass-fraction basis, however, the supply of fibres is usually at a lower cost and a reduced environmental impact, and therefore may have a better performance on a per-cost or per-impact basis. The performance data presented in this paper should help determine if this is the case where cost and impact data can be locally determined.

According to Reddy (2004) there is a need for optimum utilization of available energy resources and raw materials to produce simple, energy efficient, environment friendly and sustainable building alternatives and techniques to satisfy the increasing demand for buildings. Earth is affordable and available and would be appropriated in the case of low cost house construction in many countries (Zami \& Lee, 2011). While it may be desirable that policy makers incorporate earth construction in their housing policy to provide decent accommodation for their people, especially in areas where housing deficits are high, there is still a considerable negative perception to earth as a building material. Continued work is needed to convince them of earth's strength and durability (Heathcoat, 1995). The present review suggests that the strength properties of soil blocks have been enhanced as indicated in the previous studies. This implies that some of the problems associated with earth construction faced by users or occupants can be addressed with the careful inclusion of fibres and binders. Knowledge of the abilities of these additives may build confidence in the users of earth construction and reduce the negative impression that earth is an inferior material for constructing houses. Further, the quantitative data presented should help policy makers and planners make reasoned choices when specifying materials for building.

The major drawback of earth as construction material is the durability especially when in contact with water. However, few studies have been conducted on durability properties whereas most of the studies are geared towards physico-mechanical properties. Ideally, it will be more beneficial if researchers and practitioners devote good percentage of their research into improving the durability properties of enhanced soil blocks. This implies that researchers and practitioners need to know the right content of fibre to be used for stabilising soil blocks and also check the amount of binders to be used in order not to erase the sustainable aspect of earthen construction.

This paper reviewed existing published studies on the effect of stabilisation on the performance characteristics of soil blocks. However, there are numerous other factors that can affect the engineering properties of a soil block. The methodology used may also consider other factors 
such as formation pressure, soil selection, curing or drying methods and optimum water content. The results may further be compared to determine critical factors and interactions. The current study focused on enhanced soil blocks, however the methodology applied can also be employed to review the performance characteristics of rammed earth construction from its published literature. In addition, future studies may consider delving into critical analysis of stabilizers or additives that are more sustainable to help practitioners make decision on which of them to use. 


\section{References}

Achenza, M., \& Fenu, L. (2006). On earth stabilization with natural polymers for earth masonry construction. Materials and Structures, 39, 21-27.

Akbulut, S., Arasan, S., \& Kalkan, E. (2007). Modification of clayey soils using scrap tire rubber and synthetic fibers. Applied Clay Science, 38, 23-32.

Al-Sakkaf, Y. K. A. (2009). Durability Properties of Stabilized Earth Blocks. (PhD. Thesis ), Universiti Sains Malaysia.

Alavez-Ramirez, R., Montes-Garcia, P., Martinez-Reyes, J., Altamirano-Juarez, D. C., \& Gochi-Ponce, Y. (2012). The use of sugarcane bagasse ash and lime to improve the durability and mechanical properties of compacted soil blocks. Construction and Building Materials, 34, 296-305.

Arumala, J. O., \& Gondal, T. (2007). Compressed Earth Building Block for Affordable Housing. London, United Kingdom: RICS Publishers.

Atzeni, C., Pia, G., Sanna, U. \& Spanu, N. (2008). Surface Wear Resistance of Chemically or Thermally Stabilized Earth-Based Materials. Materials and Structures, 41(4), 751-758

Aymerich, F., Fenu, L., \& Meloni, P. (2012). Effect of reinforcing wool fibres on fracture and energy absorption properties of an earthen material. Construction and Building Materials, 27, 66-72.

Bahar, R., Benazzoug, M., \& Kenai, S. (2004a). Performance of compacted cement-stabilised soil. Cement \& Concrete Composites, 26, 811-820.

Banthia, N. (2005). Fiber Reinforced Concrete. . In V. University of British Columbia, Canada. (Ed.). Canada.

Bhatta, \& Basudeb. (2010). Analysis of Urban Growth and Sprawl from Remote Sensing Data. Advances in Geographic Information Science, Springer, 23-42.

Binici, H., Aksogan, O., \& Shah, T. (2005). Investigation of fibre reinforced mud brick as a building material. Construction and Building Materials, 19, 313-318.

Bouhicha, M., Aouissi, F., \& Kenai, S. (2005). Performance of composite soil reinforced with barley straw. Cement \& Concrete Composites, 27, 617-621.

Burroughs, S. (2006). Strength of Compacted Earth: Linking Soil Properties to Stabilizers. Building Research and Information, 34(1), 55-65. doi:10.1080/09613210500279612.

Cai, Y., Shi, B., Ng, C. W. W., \& Tang, C. (2006). Effect of polypropylene fibre and lime admixture on engineering properties of clayey soil. Engineering Geology, 87, 230-240.

Chan, C. M. (2011). Effect of Natural Fibers Inclusion in Clay Bricks: Physico-Mechanical Properties. International Journal of Civil and Environmental Engineering, 3(1), 51-57.

Chanh, N. V. (2002). Steel Fiber Reinforced Concrete. In H. C. M. C. U. o. Technology (Ed.). China.

Danso, H. (2013). Building houses with locally available materials in Ghana: benefits and problems. International Journal of Science and Technology, 2(2), 225-231.

Degirmenci, N. (2008). The using of waste phosphogypsum and natural gypsum in adobe stabilization. Construction and Building Materials, 22, 1220-1224.

Delgado, M. C. J., \& Guerrero, I. C. (2006). Earth building in Spain. Construction and Building Materials, 20, 679-690.

Delgado, M. C. J., \& Guerrero, I. C. (2007). The selection of soils for unstabilised earth building: A normative review. Construction and Building Materials, 237-251, 237-251.

Demir, I. (2006). An investigation on the production of construction brick with processed waste tea. Building and Environment, 49(1), 1274-1278.

Eko, R. M., Offa, E. D., Ngatcha, T. Y., \& Minsili, L. S. (2012). Potential of salvaged steel fibers for reinforcement of unfired earth blocks. Construction and Building Materials, 35, 340-346. 
Elenga, R. G., Mabiala, B., Ahouet, L., Goma-Maniongui, J., \& Dirras, G. F. (2011). Characterization of Clayey Soils from Congo and Physical Properties of Their Compressed Earth Blocks Reinforced with Post-Consumer Plastic Wastes. Geomaterials, 1, 88-94.

Galán-Marín, C., Rivera-Gómez, C., \& Petric, J. (2010). Clay-based composite stabilised with natural polymer and fibre. Construction and Building Materials, 20(8), 1462-1468.

Gaw, B., \& Zamora, S. (2011). Soil Reinforcement with Natural Fibers for Low-Income Housing Communities. (MSc), Worcester Polytechnic Institute.

Ghavami, K., Filho, R. D. T., \& Barbosac, N. P. (1999). Behaviour of composite soil reinforced with natural fibres. Cement and Concrete Composites, 21, 39-48.

Gooding, D. \& Thomas, T. (1997). Soilcrete Blocks: Experimental Work to Determine Whether Cement or Compaction Pressure Is More Effective. Building Research \& Information, 25(4), 202-209. doi:10.1080/096132197370327.

Guettala, A., Houari, H., Mezghiche, B., \& Chebili, R. (2002). Durability of lime stabilized earth blocks. Courrier du Savoir, 2, 61-66.

Harper, D. (2011). Alternative Methods of Stabilisation for Unfired Mud Bricks. A thesis submited to School of Civil Engineering \& Geosciences, Newcastle University: Engineers Without Borders. Available at: http://www.ewb-uk.org/filestore/20110514-Mud\%20brick\%20construction.pdf

Heathcote, K. A. (1995). Durability of earthwall buildings. Construction and Building Materials, 9, 185189.

Heathcote, K. A. (2002). An investigation into the erodibility of earth wall units. (PhD Thesis), University of Technology, Sydney.

Hejazi, S. M., Sheikhzadeh, M., Abtahi, S. M., \& Zadhoush, A. (2012). A simple review of soil reinforcement by using natural and synthetic fibres. Construction and Building Materials, 30, 100-116.

Hossain, K. M. A., Lachemi, M., \& Easa, S. (2007). Stabilized soils for construction applications incorporating natural resources of Papua New Guinea. Resources, Conservation and Recycling, $51,711-731$.

Hossain, K. M. A., \& Mol, L. (2011). Some engineering properties of stabilized clayey soils incorporating natural pozzolans and industrial wastes. Construction and Building Materials, 25, 3495-3501.

Houben, H., \& Guillaud, H. (1994). Earth construction: a comprehensive guide. London: International Technology Publications.

Ismail, S., \& Yaacob, Z. (2011). Properties of Laterite Brick Reinforced with Oil Pal Empty Fruit Bunch Fibres. Pertanika Journal of Science and Technology, 19(1), 33-43.

Juárez, C., Guevara, B., Valdez, P., \& Durán-Herrera, A. (2010). Mechanical properties of natural fibers reinforced sustainable masonry. Construction and Building Materials, 24, 1536-1541.

Kavas, T. (2006). Use of boron waste as a fluxing agent in production of red mud brick. Building and Environment, 41, 1779-1783.

Kinuthia, J., \& Mofor, L. (2010). Sustainable Construction Materials in Africa: a Pilot Study of Kenya and Cameroon: UNESCO Cymru-Wales Committee.

Kouakou, C. H., \& Morel, J. C. (2009). Strength and elasto-plastic properties of non-industrial building materials manufactured with clay as a natural binder. Applied Clay Science, 44, 27-34.

Lawrence, M., Heath, A., \& Walker, P. (2008). Mortars for thin unfired clay masonry walls. International conference on Building with earth, LEHM 2008

Kumar, A., Walia, B. S., \& Mohar, J. (2006). Compressive strength of fibre reinforced highly compressible clay. Construction and Building Materials, 20, 1063-1068.

Labib, W., \& Eden, N. (2004). An Investigation Into The Use Of Fibres In Concrete Industrial Ground-Floor Slabs. . Liverpool John Moores University, Liverpool. 
Li, V. C. (2002). Large volume, high-performance applications of fibres in civil Engineering. Journal of Applied Polymer Science, 83(3), 660-686.

Maher, M. H., \& Ho, Y. C. (1994). Mechanical properties of kaolinite/fibre soil composition. Journal of Geotechnical Engineering, 120(8), 1381-1393.

Millogo, Y., Hajjaji, M. \& Ouedraogo, R. (2008). Microstructure and Physical Properties of Lime-Clayey Adobe Bricks. Construction and Building Materials, 22(12), 2386-2392. doi:10.1016/j.conbuildmat.2007.09.002.

Millogo, Y. \& Morel, J. C. (2012). Microstructural Characterization and Mechanical Properties of Cement Stabilised Adobes. Materials and Structures, 45(9), 1311-1318. doi:10.1617/s11527-012-9833-2.

Millogo, Y., Morel, J.-C., Aubert, J.-E. \& Ghavami, K. (2014). Experimental Analysis of Pressed Adobe Blocks Reinforced with Hibiscus Cannabinus Fibers. Construction and Building Materials, 52, 7178. doi:10.1016/j.conbuildmat.2013.10.094.

Minke, G. (2009). Building with Earth, design and technology of a sustainable architecture Basle: Birkhäuser.

Montgomery, D. E. (2002). Dynamically-compacted cement stabilised soil blocks for low-cost walling. (PhD Thesis), University of Warwick, Warwick.

Morel, J., Pkla, A. \& Walker, P. (2007). Compressive strength testing of compressed earth blocks. Construction and Building Materials, 21, 303-309. doi:10.1016/j.conbuildmat.2005.08.021.

Muntohar, A. S. (2011). Engineering characteristics of the compressed-stabilized earth brick. Construction and Building Materials, 25, 4215-4220.

Ngowi, A. B. (1997). Improving the traditional earth construction: a case study of Botswana. Construction and Building Materials, 11(1), 1-7.

Obonyo, E., Tate, D., Sika, V. \& Tia, M. (2010a). Advancing the Structural Use of Earth-based Bricks: Addressing Key Challenges in the East African Context. Sustainability, 2, 3561-3571.

Obonyo, E., Exelbirt, J. \& Baskaran, M. (2012b). Durability of Compressed Earth Bricks: Assessing Erosion Resistance Using the Modified Spray Testing. Sustainability, 2, 3639-3649.

Oti, J. E., Kinuthia, J. M., \& Bai, J. (2009). Unfired clay bricks: from laboratory to industrial production. Proceedings of the Institution of Civil Engineers. Engineering Sustainability, 162, 229-237.

Oti, J. E. \& Kinuthia, J. M. (2012). Stabilised Unfired Clay Bricks for Environmental and Sustainable Use. Applied Clay Science, 58, 52-59. doi:10.1016/j.clay.2012.01.011.

Pacheco-Torgal, F., \& Jalali, S. (2012). Earth construction: Lessons from the past for future eco-efficient construction. Construction and Building Materials, 29, 512-519.

Piattoni, Q., Quagliarini, E., \& Lenci, S. (2011). Experimental analysis and modelling of the mechanical behaviour of earthen bricks. Construction and Building Materials, 25, 2067-2075.

Quagliarini, W., \& Lenci, S. (2010). The influence of natural stabilisers and natural fibres on the mechanical properties of ancient Roman adobe bricks. Journal of Cultural Heritage, 11(1), 309314.

Ren, K. B., \& Kagi, D. A. (1995). Upgrading the durability of mud bricks by impregnation. Building and Environment, 30, 433-440.

Reddy, B. V. V., Lal, R. \& Rao, K. S. N. (2007). Optimum Soil Grading for the Soil-Cement Blocks. Journal of Materials in Civil Engineering, 19(2), 139-148. doi:10.1061/(asce)0899-1561(2007)19:2(139).

Reddy, B.V.V. (2004). Sustainable Building Technologies. Current Science, 87(7), 899-907.

Reddy, B. V. V. \& Hubli, S. R. (2002). Properties of Lime Stabilised Steam-Cured Blocks for Masonry. Materials and Structures, 35(249), 293-300.

Reddy, B. V. V. \& Lokras, S. S. (1998). Steam-Cured Stabilised Soil Blocks for Masonry Construction. Energy and Buildings, 29(1), 29-33. doi:10.1016/s0378-7788(98)00033-4.

Riza, F. V., Rahman, I. A., \& Zaidi, A. M. A. (2011). Preliminary Study of Compressed Stabilized Earth Brick (CSEB). Australian Journal of Basic and Applied Sciences, 5(9), 6-12. 
Sen, T., \& Reddy, H. N. J. (2011). Application of Sisal, Bamboo, Coir and Jute Natural Composites in Structural Upgradation. International Journal of Innovation, Management and Technology, 2(3), 186-191.

Turgut, P., \& Yesilata, B. (2008). Physico-mechanical and thermal performances of newly developed rubber-added bricks. Energy and Buildings, 40(5), 679-688.

Turkish Standard (TS 704). (1983). Clay bricks-Wall Tile: Turkish Standard Institution.

Turkish Standard (TS 704). (1985). Solid brick and vertically perforated bricks (the classification, properties, sampling, testing and marking of solid bricks and vertically perforated bricks): Turkish Standard Institution

UN Habitat (2008). Low-Cost Sustainable Housing, Materials and Building Technology in Developing Countries: UN Habitat

UN Habitat (2011). Affordable land and housing in Africa. United Nations Human Settlements Programme (Vol. 3). Nairobi, Kenya: UN Habitat.

Vairagade, V. S., \& Kene, K. S. (2012). Introduction to Steel Fiber Reinforced Concrete on Engineering Performance of Concrete. . International Journal of Scientific \& Technology Research, 1(4), 139141.

Vilane, B. R. T. (2010). Assessment of stabilisation of adobes by confined compression tests. Biosystems Engineering, 106, 551-558.

Villamizar, M. C. N., Araque, V. S., Reyes, C. A. R., \& Silva, R. S. (2012). Effect of the addition of coal-ash and cassava peels on the engineering properties of compressed earth blocks. Construction and Building Materials, 36, 276-286.

Walker, P. \& Stace, T. (1997). Properties of Some Cement Stabilised Compressed Earth Blocks and Mortars. Materials and Structures, 30, 545-551. doi:10.1007/bf02486398.

Walker, P. J. (1995). Strength, durability and shrinkage characteristics of cement stabilised soil blocks. Cement \& Concrete Composition, 17, 301-310. doi:10.1016/0958-9465(95)00019-9.

Walker, P. (2000). Strength and durability testing of earth blocks. In: Proceedings of the 6th international seminar on structural masonry for developing countries, Bangalore, India.

Walker, P. J. (2004). Strength and Erosion Characteristics of Earth Blocks and Earth Block Masonry. Journal of Materials in Civil Engineering, 16(5), 497-506. doi:10.1061/(asce)08991561(2004)16:5(497).

Yalley, P. P., \& Kwan, A. S. K. (2008). Use of Waste and Low Energy Materials in Building Block Construction. Paper presented at the 25th Conference on Passive and Low Energy Architecture (PLEA), Dublin.

Yetgin, S., Cavdar, O., \& Cavdar, A. (2008). The effects of the fiber contents on the mechanic properties of the adobes. Construction and Building Materials, 22, 222-227.

Zami, M.S., \& Lee, A (2011). Widespread adoption of contemporary earth construction in Africa to address urban housing crisis. The Built and Human Environment Review, 4(2), 85-96. 